Beata Rogowska

Jan Kochanowski University in Kielce

Faculty of Law, Management and Administration

e-mail: beata.rogowska@ujk.edu.pl

\title{
Ethical aspects of normative theories of accounting*
}

\begin{abstract}
The aim of this article is to show ethical aspects of the so-called normative accounting theory (NT), with particular emphasis on the ethical and normative theory (ENT), important for the development of accounting as a science, taking into consideration its social function. Attention is focused on the so-called axiological layer with regard to the methodological foundation (pragmatic methods and related metascience) concerning the work of theorists in Western Europe. Although in the years 70 s shall be considered as unscientific and begin the process of domination positive theory of accounting. It seems that the $21^{\text {st }}$ century has brought about a rebirth of specific ethical and social topics in the field of accounting.

The importance and usefulness of ethics in accounting have been growing due to changes in accounting and social needs driven by a turbulent environment, as well as changes in science.
\end{abstract}

Keywords: methodology, ethics, normative theories, accounting

JEL Classification: M40, M41, M49

\footnotetext{
* The article is an updated version of the paper published in Polish in the Annales. Ethics in Economic Life, 19(3), 99-112.
} 


\section{Introduction}

The aim of the article is to analyse ethical aspects of accounting at the theoretical level. ${ }^{1}$ The adopted research method is based on a literature review. The nature of the relationship between ethics and accounting is determined to a large extent by the character of accounting as a science. ${ }^{2}$

Normative theories (NT) of accounting, which are part of the so-called alternative theories, are one of the key aspects of the formation of the scientific and social character of accounting as a science.

\section{Ethics and accounting}

Economic activity is not a morally neutral sphere, ${ }^{3}$ although moral issues are difficult to quantify. Currently, in the real socio-economic life, high social "demand" for ethical issues can be seen. Despite the fact that ethical issues seemingly do not concern accounting, ${ }^{4}$ contemporary changes in the accounting environment, e.g., the financial crisis, mean that accounting cannot afford the "loss of trust" (Wójtowicz, 2000, p. 133).

The aim of ethics ${ }^{5}$ is to search for sources of morality, exploring the effects of morality, or lack thereof, on people and to seek basic philosophical premises on the basis of which moral requirements can be created rationally along with an ordered set of normative and directive convictions that would uniformly regulate

\footnotetext{
${ }^{1}$ The theoretical area of accounting is particularly characteristic of management and financial accounting (Maślankowski, 2009, p. 109).

2 Accounting is rooted in practice. In the academic discourse on accounting, it is emphasised that accounting is a science that is still searching for proof that it is a science. According to the Regulation of the Ministry of Science and Higher Education of 2011, it is not formally and legally a separate entity. Its characteristic feature is a close connection with the discipline of economics (visible gradual independence) (Cieślak, 2011, p. 33; Jastrzębowski, 2014, p. 99).

${ }^{3}$ Consistency between moral and legal standards seems to be particularly important (Pogonowska, 2000, p. 10).

${ }^{4}$ For example, Havel simplifies the importance of accounting as a science by saying: "But what is the point of accounting if what shapes our lives is difficult or impossible to count? I wonder what an economist/accountant would do if he or she got the job of optimising a symphony orchestra? The answer is as follows: it would eliminate all pauses from Beethoven's concerts. In the age of world complexity and increasing social expectations, this view (in quantitative terms) of accounting is contested. It is difficult to retain research methods neutral in terms of evaluation in disciplines related to social and human aspects" (Sedláček, 2011, pp. 9-10).

${ }^{5}$ Ethics is a concept very often confused with morality treated as a social phenomenon, which is the subject of research of ethics understood as a science. Morality is the total sum of judgements that dominate in a given era or environment, as well as the norms, principles and ideals that define certain views and behaviours as appropriate.
} 
all areas of public and private life. ${ }^{6}$ In addition, it emphasises values "difficult to interpret" for economists, such as justice, truth and honesty. ${ }^{7}$

Two specific ethics, which are neither identical nor exclusive, seem to be extremely important for accounting. The first is management ethics (in the market economy system), which is a reflection on the moral context of this sphere of social relations. ${ }^{8}$ The other one is business ethics, which is distinguished within broad economic ethics as its dominant area and as the field of ethical reflection focused on people playing the role of entrepreneurs in companies (the subject of analysis is, among others, the sense of duty of representatives of this group, taking into account social values applied in running a business) (Filek, 2001, p. 14). It seems that this ethics is closer to the issues faced by accounting. This is particularly evident when accounting is considered as a universal international business language that enables communication among all participants of economic life. ${ }^{9}$

At present, the following division of general ethics exists:

(1) metaethics (Kant, Hume) focusing on questions concerning the essence, nature or ontological status of ethical concepts;

(2) normative ethics answering the question of how to behave (setting standards and norms of conduct) ${ }^{10}$

(3) postmodern ethics (relativism), according to which values, norms and assessments are relative, dependent on the place and the evaluator. ${ }^{11}$

Taking into account two extreme positions, the following should be distinguished:

(1) utilitarianism (a typically economic approach aimed at maximising profit) whose name comes from utilitas, i.e. a benefit (utility). It was created on the basis of Protestant ethics as an expression of consequential ethics. ${ }^{12}$ This approach states that an act is ethical as long as it brings a good (in terms of its utility) result. ${ }^{13}$

\footnotetext{
${ }^{6}$ In the theoretical sphere, ethics, economics and accounting science are distinguished, while in the practical sphere-morality, business (management) and accounting practice (Klimczak, 2006, p. 40).

They are expressed in accounting principles (true and fair view, fair value) (Ciastoń \& Mandecka, 2014, p. 93).

${ }^{8}$ Systemically and institutionally, these issues also fall within the area of social philosophy and social ethics (Dietl \& Gasparski, 2002, p. 74).

${ }^{9}$ This is not a novel approach as examples of medieval accounting ethics are known. Cortuglio or Matthew from Cracow used the so-called Rule of the Master and St. Benedict's Rule as well as theses of "the father of accounting"-L. Pacioli (1494). It should be emphasised that the first ethical concepts were created within the framework of the American Association of Public Accounting (AAPA) in 1905 (Garstka, 2015; Turzyński, 2013, p. 138).

${ }^{10}$ Two approaches of Baker (2015) are used in accounting, as they come together in the following question: how do you know that a given issue is an ethical one? In the epistemological dimension, ethical issues are perceived as determined by individual decision makers (atomistic view) or by social and historical factors (social view). The latter approach is normative. In addition, we can also deal with a combination of epistemological and normative dimensions (p. 267).

${ }^{11}$ Descriptive ethics is mentioned as the third one (Gaffikin, 2007, pp. 3-5).

${ }^{12}$ Utilitarianism was created by Bentham, who presented a moral doctrine based on the overriding norm of the Greatest Happiness Principle.

${ }^{13}$ There are two approaches to normative ethics: consequentialist and deontological (Ketz, 2006, p. 48; Vasiljeviene, 2005, pp. 48-49).
} 
(2) Kantian ethics, which comprises the ethics of duty, ethical absolutism (social approach), ${ }^{14}$ deontological ethics (acts independent of consequences) and autonomous ethics (a lack of external authority) (Klimczak, 2006, p. 46). It comes down to an absolute internal moral imperative ("ethical practical reason") that can provide a universal basis for human behaviour. ${ }^{15}$

\section{The specificity of ethical and normative theories}

Attempts to create an accounting theory in order to improve accounting practice have been made mainly in the $21^{\text {st }}$ century. ${ }^{16}$ The division into positive (PT) and normative theories (NT) is part of the relationship between positive economics (the neoclassical core) and normative economics. ${ }^{17}$

Accounting was positioned primarily within positive economics. The concept of normative accounting was introduced by Mattessich in the encyclopaedia of Chatfield and Vangermeersch. ${ }^{18}$ It can be applied based on two basic meanings: a narrow meaning - to indicate the formal determination of a norm, principle or law that articulates a particular value or set of values (prescriptive moralising) and a broader meaning - a "value-laden" one (the opposite of the term "value-free"), regardless of whether the value is articulated as a norm or not.

Normative theories are embedded in the sphere of subjectivism, i.e. they are associated with ontological idealism and epistemological rationalism. They are a product of the society in which they were created and cannot be regarded as ethically neutral. These theories consist of recommendations, conclusions, opinions, and judgments about how things should be (the desired condition). They focus on existing value systems and do not form new ones (Szychta, 2013, p. 256). Positive theories, however, only explain the economic reality (description) without assessing social and economic phenomena (Łada \& Kozarkiewicz, 2013, p. 163; Sawicki, 2013, p. 219).

\footnotetext{
${ }^{14}$ Ethics of law and justice is derived from it.

${ }^{15}$ This ethics is moving towards responsibility (this is particularly evident in the concept of Corporate Social Responsibility (CSR) analysed later).

${ }^{16}$ Accounting theories are proposals for accounting policies and practices (theory shapes practice through the accounting policy). The conclusions of some theories are recommendations for the accounting policy pursued in a given country (setting standards and rules of financial accounting) or for individual companies' policies in the field of accounting. Theory does not have to be fully applicable to practice, but it should provide a framework for new concepts (ideas and procedures), no matter when they are applied and verified. In this dimension, it is an attempt to "escape from practice" from which accounting is derived (Hendriksen \& van Breda, 2002, p. 43).

${ }^{17}$ The division into positive (value-free) economics, normative (value-laden) and the art of economics (applied economics) was introduced into economics by J.N. Keynes (Garstecki, 2012, p. 40).

${ }_{18}$ The 1950-1960 period is the "golden age" of normative research, while the period of intensive studies in this field in the United States, Australia and Canada falls between the years 1960-1970. This sort of categorisation, however, is extremely vague, as such research appeared both earlier and later. Nelson (1973) also defined the scope and nature of those studies by calling the 1960-1970 period the "golden age in the history of a priori research in accounting" (Chatfield \& Vangermeersch, 1996, p. 102).
} 
The mainstream (MS) of accounting, as well as of economics, is composed of positive studies, using research methods typical of empirical (aposterioric) sciences. This is in line with the conventional approach. ${ }^{19}$ Normative theories are usually considered unscientific and are classified under heterodoxy. ${ }^{20}$

Table 1. Positive and normative theories: Their structure and verification

\begin{tabular}{|c|c|c|}
\hline $\begin{array}{l}\text { The name of } \\
\text { the theory }\end{array}$ & Normative theories & $\begin{array}{l}\text { Positive theories-descriptive- } \\
\text { "pure" science }\end{array}$ \\
\hline Griffin's model & Taste: "valuable because desired" & Perception \\
\hline $\begin{array}{l}\text { Type of } \\
\text { knowledge }\end{array}$ & $\begin{array}{l}\text { A priori knowledge-internal type of } \\
\text { knowledge. }\end{array}$ & $\begin{array}{l}\text { A posteriori knowledge-derived from } \\
\text { the observation of everyday life (busi- } \\
\text { ness practice). }\end{array}$ \\
\hline Method & $\begin{array}{l}\text { Deduction (prescription). } \\
\text { The dominance of qualitative methods. }\end{array}$ & $\begin{array}{l}\text { Induction (prediction). } \\
\text { The dominance of quantitative meth- } \\
\text { ods. }\end{array}$ \\
\hline $\begin{array}{l}\text { General } \\
\text { characteristics }\end{array}$ & $\begin{array}{l}\text { Based on "means-ends" analysis. } \\
\text { The terms "should", "ought to" are } \\
\text { used, i.e. answers to questions about } \\
\text { how things should be are provided. }\end{array}$ & $\begin{array}{l}\text { Faithful reflection of reality. } \\
\text { For example, the effects that accounting } \\
\text { exerts on the environment are } \\
\text { explained. Questions: why? what? how? }\end{array}$ \\
\hline Conclusions & $\begin{array}{l}\text { Answers to normative questions always } \\
\text { depend on the objective function. }\end{array}$ & $\begin{array}{l}\text { Obtained answers are to be important } \\
\text { for decision-makers. They are not } \\
\text { universal in their nature. }\end{array}$ \\
\hline $\begin{array}{l}\text { Theoretical } \\
\text { basis }\end{array}$ & $\begin{array}{l}\text { Practised by people of science, account- } \\
\text { ing theorists who are looking for postu- } \\
\text { lated solutions and accounting tools } \\
\text { that better describe reality. } \\
\text { The first creators included: } \\
\text { Sprague (1907), Paton (1922) and } \\
\text { Canning (1929) }\end{array}$ & $\begin{array}{l}\text { Practised by practitioners. } \\
\text { Neoclassical theories in economics } \\
\text { (marginal economics). } \\
\text { The development of ideas: Comte, } \\
\text { Jensen, Rochester School (Watts, Zim- } \\
\text { merman, Ball, Brown), Chicago School } \\
\text { (Friedman), and agency theory. }\end{array}$ \\
\hline
\end{tabular}

Note. Adapted from "Accounting, a multiparadigmatic science," by A. Riahi-Belkaoui, 1996, Westport-London: Greenwood Publishing Group, p. 8 and "Accounting theory," 2004, Illinois: Cengage Learning EMEA, p. 398.

In the NT framework, Mattessich distinguished the following two main types:

(1) pragmatic and normative theories, classified according to the period in which they were created (1950-1975). The research mainly concerned determining the postulates and principles of financial accounting, and determining the form of modern accounting, etc. (Hendriksen \& van Breda, 2002, p. 33);

(2) conditional-normative accounting methodology-Mattessich (1992; Szychta, 1996, p. 77).

\footnotetext{
${ }^{19}$ The term "normative" is not a synonym for "deductive", just as the term "positive" is not a synonym for "inductive". No NT can exist without observing certain facts from the real economic world, and at the same time no PT can be developed without deductive reasoning (Szychta, 1996, pp. 226-227).

${ }^{20}$ In economics, there is a division into the following types of economics: conventional, orthodox and traditional as well as non-standard, unconventional, heterodox, and alternative. Mainstream researchers perceive accounting as a context-independent practice, apolitical and economically rational (neoclassical approach) and as a tool to reflect the reality of an economic entity. The symbolic transition from normative to positive theory took place in the 1970s, Peirson and Brown called PT neoempirical theories (realistic ontology). Those researchers recognised that there was an objective external reality, independent of human actions (Baxter \& Chua, 2003, pp. 97-126; Humphrey \& Lee, 2004, p. 64).
} 
Assuming that accounting does not represent a specific economic reality of an economic entity but instead creates it, accounting should bear responsibility for the social effects it causes. This approach is characterised by the use of normative ethical theories (NET) within which the subject of research has been extended to include ethical analyses.

When classifying theories according to the demographic criterion, it should be stated that the first normative ethical theories were created in the works of German scholars from the German Normative School in the $20^{\text {th }}$ century. ${ }^{21}$ In particular, the contribution of two German scholars should be emphasised: Schär and Nicklisch. ${ }^{22}$ Their theories contained an important ethical element according to which entrepreneurs should optimise performance and methods of operation for the general social good (e.g. minimise production costs for the benefit of consumers) instead of maximising corporate or personal profits. The indicated researchers preferred a holistic approach.

The British Normative School was a continuation of this approach. In the 1970s, a research trend under the leadership of Hopwood, Cooper and Powell, ${ }^{23}$ who represented an undeniably ethical approach, was established. According to Hopwood (1989, p. 141):

accounting [...] is no longer seen as merely residing in the technical domain, serving the role of a neutral facilitator of effective decision-making, accounting is slowly starting to be related to the pursuit of quite particular economic, social and political interest. ${ }^{24}$

Therefore, it cannot be separated from the environment to function neutrally in relation to other entities. As a result of evolutionary processes, corresponding to the level of development, accounting has become an important component of modern management on the scale of economic and social organisation (Kaczocha, 2015, p. 247).

\footnotetext{
${ }^{21}$ In the history of Germany, the Fugger family and the academic traditions of German accounting are closely related to the development of business administration. Important figures include the lawyer Simon and Professor Schmalenbach — the creator of dynamic accounting theory, who adopted a normative ethical approach to accounting theory, which is evident in the original edition of his works: Dynamische Bilanz and Kostenrechnungund Preispolitik. Later he gave up the ethical-normative approach, limiting himself to the maxim that "waste should be avoided" (Biondi \& Zambon, 2013; Fülbier \& Gassen, 2011, p. 13).

${ }^{22}$ The first one was a pioneer of accounting ethics, a professor in Zurich and Berlin, the author of the first theory of accounting. For Nicklisch, a philosophical approach in business is the key to understanding and explaining economic phenomena. He draws attention not only to empirical research but also to values and social norms. Philosophy such as idealism, materialism and romanticism had a significant influence on it. Like Fichte, he stressed the role of society and responsibility towards the community. The publications of Schär and Nicklisch were not scientific works on accounting.

${ }^{23}$ In 1975, Hopwood established a journal entitled Accounting, Organizations and Society. In this particular journal alone, in the years 1980-2003, 91 articles whose authors reflected on the issues related to accounting practice in reference to Foucault's works were published. He held the position of the editor from 1976 to 2009. In 1977, he became the main founder of the European Association of Accountants (Chapman, Cooper \& Miller, 2009, pp. 10, 30; Miller, 2010, pp. 1-5).

${ }^{24}$ It is characterised by relatively low predictability, a lack of universalism and the use of qualitative elements which are difficult to measure (Hopwood, 1989, p. 141).
} 
As part of this approach, which has found its continuation also on the American continent, two varieties can be distinguished:

(1) moderate approach. Interpretative studies were focused on understanding the social nature of accounting. Their goal was not to criticise and promote radical social change but to explain and show facts and relationships. ${ }^{25}$ The proponents of this approach claimed that accounting must reflect the changing ontological, epistemological, methodological and logical assumptions that appeared in other social sciences. ${ }^{26}$ In the light of this approach, accounting was not created only by capitalism, industrialisation, ownership or organisational structures. Its creation and functioning were seen as a rather complex phenomenon due to the interweaving of many different influences. The hermeneutic philosophy (explaining the relation of the individual to the community) is also important in this dimension, including the ethical interpretations of such philosophers as Heidegger, Gadamer or Ricoeur which provide the theoretical basis for the analysis of broadly understood ethics in accounting. ${ }^{27}$

(2) critical accounting research which is a development of the moderate approach and is embedded in the Kantian tradition (it has been developed since the 1980s). Representatives of this research tradition conduct an extensive analysis of the hermeneutical role of accounting (as a method of human activity leading to the location of its factors in the social environment) and its place as an information system. ${ }^{28}$

\footnotetext{
${ }^{25}$ It refers to the social philosophy of Foucault and Derrida (who writes about responsibility). The interest in the ideas proclaimed by Foucault in accounting began in the late 1970s in Great Britain. Concepts such as "knowledge," "discourse," "power" or "disciplinary society" are the main components of his theory. In the works of Foucault, issues of the philosophy of power (why the social order in the modern world is increasingly less based on external strength and control and increasingly more on the internal disciplining of individuals) occupy a special place. This is the basis of many studies brought together under the name of governmentality. From his perspective, ethics concerns the relationship that a person should have with him or herself and the way in which a person perceives and creates him or herself as a moral subject (Benton \& Craib, 1993, pp. 191-192).

${ }^{26}$ In this case, it is important to consider four paradigms of Burrell and Morgan, who proposed a typology based on two dichotomous meta-metrical dimensions: assumptions about the nature of science (objectivism-subjectivism dimension) and assumptions about the nature of society (regulationradical change dimension) (Laughlin, 1987, pp. 479-502).

${ }^{27}$ Hermeneutics is a science dealing with studying, explaining and interpreting written sources in order to determine their proper content and accurate meaning. One can also encounter the definition of the hermeneutic circle. According to this definition, the understanding of the whole is achieved on the basis of the understanding of its components, and the understanding of the components is based on the understanding of the whole. As in the case of dialectical thinking, the whole is important, and the process of thinking is treated as "moving back and forth between the whole and the part." Consequently, any objective examination is not possible, and truth only exists as a shared interpretation. Knowledge can be considered knowledge only if it is accepted by observers (Garstecki, 2012, pp. 44 47).

${ }^{28}$ An important distinction of critical theory is the rejection of positivism as the sole arbitrator and creator of knowledge. The studies of the critical trend of accounting are mainly presented by the journal entitled Critical Perspectives on Accounting established by Tinker, Lowe and Cooper. Many works are also published in Accounting, Auditing \& Accountability Journal. As befits an alternative trend, these journals are not on the list of high impact factor scientific journals, which reflects the status and reputation of the journals in the scientific community (Mućko, 2013, p. 82).
} 
This approach was created primarily by social theorists and philosophers, including Horkheimer, Adorno, and Habermas, ${ }^{29}$ who cooperated at the Institute for Social Research in Frankfurt in the 1920s, and who are colloquially referred to as the Frankfurt School. ${ }^{30}$

Habermas's ethics of discourse (communication) played a significant role in this dimension. ${ }^{31}$ The ethical approach from this perspective assumes that the internal contradictions of capitalism (instability, injustice), especially in the AngloSaxon version, cause ethical problems. Therefore, research in the field of accounting should lead to an exploration of power and conflict in society, and should, therefore, focus on the impact of accounting reports on the distribution of profit and value. State-controlled accounting regulations are also important, in particular, in social and environmental areas, preventing the so-called "dirty business".

From the perspective of accounting as a science, the control function is of particular importance in an ethical context, as indicated by Burzym. ${ }^{32}$ Its development allows one to determine the social function of accounting, referred to as a stimulus function, ${ }^{33}$ which concerns the socio-economic rationalisation of management and the implementation of economic decisions in enterprises and institutions, including an ethical reflection on and the ethical effects of undertaken activities. ${ }^{34}$ In this way, it becomes a social good through the socialisation of control

\footnotetext{
${ }^{29}$ As well as: Armstrong, Chua and Cooper. There are three main stages in the development of this approach: the first — until the mid-1970s, the second - encompassing later works of Habermas, and the third - concerning the works of Habermas's students. The works of the University of Sheffield are a continuation of his approach (Lowe, Tinker). The proponents of critical theory also include Laughin, who believed that critical accounting is always contextual, has social, political and economic consequences, is undertaken to introduce change, i.e. improvement, covers the micro and macro sphere, and is interdisciplinary (Laughlin, 1999, p. 77; Roslender, 2006, p. 253).

${ }^{30}$ They operated at the University of Frankfurt am Main in 1923-1932, and from 1933, subsequently: in Paris at Ecole Normale Superieure and in New York at Columbia University, then after 1949 again in Frankfurt. In the course of forty years, this school evolved from criticism to describing the capitalist society, its affirmation and criticism of socialism. Important figures influencing the development of the school were: Lukacs (inspired by the theories of young Marx), who proposed the analysis of the role of superstructure factors in society, e.g. ideology, literature, art, etc. In addition, Gramsci, who was involved in the promotion of Marxist theory in Italy and showed the capitalist domination even with regard to accounting, stating that "accounting is a product of an elite group" (Bobryk \& Zychowicz, 2006, p. 5; Dubiel, 1981; Roslender, 2006, p. 249).

${ }^{31}$ According to him, discourses are organisations and social structures that reflect the life-world (systems). In addition, they create mechanisms that are to help the systems reflect the needs of the lifeworld (steering media). Thus, discursive and effective communication is introduced, which enables conflicts to be resolved through discourse. He therefore created a new basis for social values and norms: a communication community (Klimczak, 2006, p. 81).

${ }^{32}$ Accounting fulfils a number of functions, for example: information, analytical and reporting, evidential, optimisational, motivational, and attestation (compliance with a set of rules) functions (Samelak, 2009, p. 10).

${ }^{33}$ The purpose of accounting is to present the internal and external effects of business operations from a social point of view (Szot-Gabryś, 2013, p. 79).

${ }^{34}$ Accounting stimulates ethical actions in this respect if the numerical image of economic activity and its results communicated to the public are characterised by transparency, reliability and international predictability regarding the methods of counting and communicating. This means creating barriers that limit anti-social behaviour (Burzym, 2008, p. 83).
} 
and evaluation, and through the application (on an ever-wider scale) of obligatory accountability of companies and institutions. ${ }^{35}$

NETs also include the third trend of social responsibility, also known under other names, which encompasses responsibility towards the natural environment and sustainable development. It is a subset of social accounting. His proponents include such figures as: Riahi-Belkaoui, ${ }^{36}$ Gray, Owen, or Pearce (Szychta, 1996, p. 90).

The basis for these considerations is the previously indicated CSR, which is a multi-faceted and holistic issue. ${ }^{37}$ CSR means a constant commitment to ethical action and contributing to economic development as well as the improvement of the quality of life of employees and their families, the local community, and society as a whole. It is also a concept of voluntarily taking into consideration social and environmental aspects by organisations. CSR means focusing on profits while at the same time respecting the law and the principles of ethical conduct as well as supporting the environment and society. In this dimension, three main types of responsibility are emphasised: economic — profit making, legal—compliance with the law, and philanthropy - charity and ethics. ${ }^{38}$

The implementation of social responsibility requires an adequate source of information, which is always corporate social responsibility accounting, social accounting ${ }^{39}$ or social and economic accounting. ${ }^{40}$ Currently, there is no comprehensive and cohesive concept of social responsibility accounting (it is analysed in the context of financial or management accounting). According to the postulate of Gabrusewicz, it should be created using normative methods. Social responsibility accounting measures and publishes information that takes into consideration the burdens and benefits for society resulting from the activity of a specific economic entity shown in a descriptive or qualitative form, indicates the places where these burdens and benefits are created, and applies an ethical approach throughout the

\footnotetext{
${ }^{35}$ Ethics, professionalism and accountability are accounting values and can be considered as foundations of accounting. "Accountability means an obligation to provide an account (not necessarily a financial one) or a list of activities for which someone is responsible. It is also the responsibility of those who rule for their choices, decisions and actions." It began to develop when universities introduced a system for assessing students' development through examinations (Gabrusewicz, 2010, p. 13).

${ }^{36} \mathrm{He}$ dealt with, among others, the issue of the influence of behavioural factors on accounting and the relationship between economic phenomena and data derived from accounting and other areas. They are based on assessments of the workforce, consumers, the local environment, etc. He emphasised the importance of morality in accounting: honesty, ethics, social responsibility and truth. He took into consideration such ethical perspectives as utilitarian and deontological ones as well as the notion of rightness (Riahi-Belkaoui, 1992).

${ }^{37}$ The main sources of CSR according to Filek (2013) are philosophical (a new paradigm of responsibility), ethical and business (business ethics as the first stage that facilitated the understanding of the philosophical paradigm of responsibility) and political (democracy) (pp. 13, 95).

${ }^{38}$ In the economic dimension, the ethically desirable effect called Pareto optimality plays an important role. This effect loses significance in the context of public goods, therefore a wider ethical approach is needed (Paliwoda-Matiolańska, 2014).

${ }^{39}$ It is perceived in microeconomic and macroeconomic terms. Riahi-Belkaoui distinguishes it from the so-called socio-economic accounting. Social accounting was initiated by Hicks in 1942 (Filek, 2013, pp. 158-159).

${ }^{40}$ Derivative ideas have also developed, e.g.: environmental accounting (Szychta, 2007, p. 70).
} 
process of measuring and presenting the burdens and benefits to society (Gabrusewicz, 2010, p. 60). In this area, research aims to induce changes in existing systems and forms of accounting that extend the scope of captured events, information needs, users, and reporting units, as well as the language and nature of data. $^{41}$

\section{Conclusions}

It should be emphasised that the research carried out in the framework of normative theories has been of great importance for the development of accounting as an applied social science and has constituted a preparatory phase for starting empirical research in accounting, and thus - for initiating considerations of its ethical dimension in practice. It has been a "big step" towards taking into consideration value in the framework of accounting. At present, there is a trend observed in economics to expand the influence of heterodox economics. It seems that this will also apply to modern accounting as "the accounting theorist deals with ethical issues at every turn" (Gabrusewicz, 2010, p. 60). Expectations towards accounting in this regard are constantly growing. At this point, however, the analysis touches on the issue of empirical research, which goes beyond the scope of this article. ${ }^{42}$

\section{References}

Baxter, J., \& Chua, W. F. (2003). Alternative management accounting research - whence and whither. Accounting, Organization and Society, 28(2), 97-126.

Benton, T., \& Craib, I. (1993). Filozofia nauk społecznych. Wrocław: Wydawnictwo Dolnośląskiej Szkoły Wyższej Edukacji TWP.

Biondi, Y., \& Zambon, S. (Eds.) (2013). Accounting and business economics. Oxford: Routledge.

Bobryk, R., \& Zychowicz, J. (Eds.) (2006). Z punktu widzenia szkoły frankfurckiej. Siedlce: Akademia Podlaska.

Burzym, E. (2008). Społeczna funkcja rachunkowości. Zeszyty Teoretyczne Rachunkowości, 45(101), 71-86.

\footnotetext{
${ }^{41}$ Science and practice have not developed any universal tool enabling the efficient measurement of benefits resulting from pro-social and pro-environmental activities. The concepts of this responsibility are often proposed in the form of separating environmental costs (cost accountinformation and audit subsystem in the accounting system) from the typical financial reporting. Another problem for accounting theory is CSR measurement (Szot-Gabryś, 2013, p. 78).

${ }^{42}$ This is evidenced by the existence of contemporary organisations focused on ethics, e.g.: the Association for Practical and Professional Ethics or the Australian Association for Professional and Applied Ethics.
} 
Chapman, Ch. S., Cooper, D. J., \& Miller, P. B. (Eds.) (2009). Accounting Organization \& Institutions. Oxford University Press.

Chatfield, M., \& Vangermeersch, R. (Eds.) (1996). The history of accounting. An international encyclopedia. New York: Routledge Library.

Cieślak, M. (2011). Podejście etyczne w rachunkowości a jakość sprawozdań finansowych. Poznań: Wydawnictwo Uniwersytetu Ekonomicznego w Poznaniu.

Dubiel, H. (1981). The origins of critical theory: An interview with Leo Lowenthal. Telos. Critical Theory of the Contemporary, 49, 141-154. doi: 10.3817/0981049141

Feluś, M. (Ed.) (2014). Wspótczesna rachunkowość w świetle regulacji krajowych i międzynarodowych. Kraków: Wydawnictwo Uniwersytetu Ekonomicznego.

Filek, J. (2001). Wprowadzenie do etyki biznesu. Kraków: Wydawnictwo Akademii Ekonomicznej.

Filek, J. (2013). Spoleczna odpowiedzialność biznesu jako nowa wersja umowy społecznej. Kraków: Księgarnia Akademicka.

Fülbier, R. U., \& Gassen, J. (2011). German accounting tradition. EAA Newsletter, 31(3).

Gabrusewicz, T. (2010). Rachunkowość odpowiedzialności społecznej w ksztaltowaniu zasad nadzoru korporacyjnego. Warszawa: C.H. Beck.

Gaffikin, M. (2007). Accounting theory and practice: The ethical dimension. School of Accounting \& Finance, University of Wollongong, Working Paper 4. http://ro.uow. edu.au/accfinwp/2

Garstecki, D. (2012). Charakterystyka i systematyka normatywnych teorii w rachunkowości. Zeszyty Naukowe UE w Poznaniu, 233, 38-48.

Garstka, M. (2015). Problematyka etyczna w pierwszych dziełach o rachunkowości. Annales. Etyka w Życiu Gospodarczym, 18(3), 73-83.

Hendriksen, E. A., \& van Breda, M. F. (2002). Teoria rachunkowości. Warszawa: Wydawnictwo Naukowe PWN.

Hopwood, A. (1989). Accounting and the pursuit of social interest. In W. F. Chua, T. Lowe, \& T. Puxty (Eds.), Critical perspective in management control. Basingstoke: Macmillan Press.

Humphrey, Ch., \& Lee, B. (2004). The real life guide to accounting research. A behind-thescenes view of using qualitative research methods. Amsterdam-Boston-HeidelbergLondon-New York-Oxford-Paris-San Diego-San Francisco-Singapore-SydneyTokyo: Elsevier.

Jastrzębowski, A. (2014). Teoria legitymizacji a funkcje rachunkowości. Studia Oeconomica Posnaniensia, 2(4), 50-60.

Kaczocha, W. (2015). Filozofia społeczna. Warszawa: Wydawnictwo Scholar.

Ketz, J. E. (2006). Accounting ethics: Theories of accounting ethics and their dissemination (Vol. 2). London: Routledge.

Klimczak, B. (2006). Etyka gospodarcza. Wrocław: Wydawnictwo Akademii Ekonomicznej im. Oskara Langego.

Laughlin, R. (1987). Accounting systems in organisational context: A case for critical theory. Accounting Organisations and Society, 12(5), 479-502.

Laughlin, R. (1999). Critical accounting nature. Progress and prognostic. Accounting Auditing and Accountability Journal, 12(1), 73-78. 
Łada, M., \& Kozarkiewicz, A. (2013). Teoria legitymizacji w badaniach z zakresu rachunkowości. Zeszyty Teoretyczne Rachunkowości, 71(127), 161-175.

Macintosh, N. B., \& Hopper, T. (Eds.) (2015). Accounting, the social and the political: classics, contemporary and beyond. London: Elsevier.

Maślankowski, K. (2009). O współczesnych relacjach teorii i praktyki rachunkowości. Artykuł dyskusyjny. Zeszyty Teoretyczne Rachunkowości, 50(106), 97-126.

Mattessich, R. (1992). On the history of normative accounting theory: Paradigm lost, Paradigm regained? Accounting, Business \& Financial History, 2(2), 181-198.

Miller, P. (2010). Anthony Hopwood (1944-2010). EAA Newsletter, 30(2), 1-5.

Mućko, P. (2013). Nurty krytyczne w badaniach rachunkowości. Studia i Prace Kolegium Zarządzania i Finansów, 130, 79-88.

Nelson, C. L. (1973). A priori research in accounting. In N. Dopuch, \& L. Revsine (Eds.), Accounting research 1960-1970: A critical evaluation (Monograph No. 7). University of Illinois.

Paliwoda-Matiolańska, A. (2014). Odpowiedzialność spoteczna $w$ procesie zarządzania przedsiębiorstwem. Kraków: Wydawnictwo C.H. Beck.

Pogonowska, B. (Eds.) (2000). Elementy etyki gospodarki rynkowej. Warszawa: Polskie Wydawnictwo Ekonomiczne.

Riahi-Belkaoui, A. (1996). Accounting, a multiparadigmatic science. Westport-London: Greenwood Publishing Group.

Riahi-Belkaoui, A. (2004). Accounting theory. Illinois: Cengage Learning EMEA.

Rogowska, B. (2016). Etyczny aspekt teorii normatywnych rachunkowości. Annales. Ethics in Economic Life, 19(3), 99-112.

Roslender, R. (2006). Critical theory. In Z. Hoque (Ed.), Methodological issues in accounting research: theories and methods. London: Spiramus Press Ltd.

Samelak, J. (2009). Rachunkowość finansowa. Teoretyczne podstawy. Poznań: Wydawnictwo Uniwersytetu w Poznaniu.

Sawicki, K. (2013). Zakres rachunkowości jako nauki. Zeszyty Teoretyczne Rachunkowości, 71(127), 211-226.

Sedláček, T. (2011). Ekonomia dobra i zła. Warszawa: Emka.

Szot-Gabryś, T. (2013). Koncepcja rachunku kosztów i korzyści w rachunkowości odpowiedzialności społecznej przedsiębiorstwa. Warszawa: Difin.

Szychta, A. (1996). Teoria rachunkowości Richarda Mattessicha w świetle podstawowych kierunków rozwoju nauki rachunkowości. Studium metodologiczne. Warszawa: Fundacja Rozwoju Rachunkowości w Polsce.

Szychta, A. (2007). Etapy ewolucji i kierunki integracji metod rachunkowości zarządczej. Łódź: Wydawnictwo Uniwersytetu Łódzkiego.

Szychta, A. (2013). Podejścia do badań naukowych w rachunkowości. Zeszyty Teoretyczne Rachunkowości, 71(127), 243-259.

Turzyński, M. (2013). O średniowiecznej moralności kupieckiej i etyce zawodowej rachunkowości: perspektywa teorii społecznej Michaela Foucaulta. Zeszyty Teoretyczne Rachunkowości, 73(129), 131-146. 
Węgrzecki, A. (Ed.) (2005). Konflikt interesów - konflikt wartości. Kraków: Wydawnictwo Akademii Ekonomicznej.

Wójtowicz, P. (2000). Metodologiczne aspekty badań naukowych w rachunkowości. Zeszyty Teoretyczne Rachunkowości, 57(1), 133-148. 